\title{
Legitimidade e ilegitimidade no armamento de escravos: milícias privadas, negociação e criminalidade na sociedade mineira setecentista
}

\section{Legitimacy and illegitimacy in arming slaves; private militias, negociation and criminality in 18 th century society in Minas Gerais}

\author{
Ana Paula Pereira Costa*
}

\begin{abstract}
Resumo
$\mathrm{O}$ artigo tem por objetivo analisar a posse e o uso de armas pelos escravos na comarca de Vila Rica em Minas Gerais na primeira metade do século XVIII. Por um lado, busca-se evidenciar a ilegitimidade do fenômeno, ou seja, o cenário de crimes e violências decorrentes do armamento generalizado. Por outro lado, intenciona-se ressaltar sua faceta de legitimidade oriunda da dependência que a coroa portuguesa e os senhores tinham da mobilização de milícias particulares de escravos armados para a efetuação de várias diligências o que, por sua vez, revela um lado consensual da escravidão.
\end{abstract}

Palavras-chave: armas, milícias particulares de escravos, criminalidade, negociação.

\begin{abstract}
The article aims to analyze the possession and use of guns by slaves in the district of Vila Rica in Minas Gerais in the first half of the eighteenth century. On the one hand, it seeks to highlight the illegitimacy of the phenomenon, that is, the scene of crimes and violence stemming from generalized use of weapons. On the other hand, it is intended to emphasize its facet of legitimacy arising from the dependence that the Portuguese crown and the masters had on the mobilization of private militias of armed slaves for the accomplishment of several diligences which, in turn, reveals a consensual side of slavery.
\end{abstract}

Keywords: guns, private slave militias, criminality, negotiation.

*Doutora em História pela Universidade Federal do Rio de Janeiro. Professora do Departamento de História da Universidade Federal de Juiz de Fora. E-mail: anappcosta@ig.com.br 
Não é novidade que a violência e as armas constituíam-se em elementos marcantes da vida social na capitania mineira setecentista. Elas eram empregadas nas mais variadas situações que iam desde conflitos intra-elites, brigas e desavenças entre grupos subalternos, e outros tipos de crimes, até a defesa de interesses régios realizada mediante a prestação de serviços que envolviam diligências como cobrança de tributos, ataques a quilombos, defesa do território contra invasores estrangeiros. Tais ações eram realizadas tanto por oficiais patenteados das companhias de ordenanças, milícias e tropas pagas, bem como por milícias particulares formadas por escravos armados pelos senhores.

Malgrado vários trabalhos tenham contribuído para o entendimento do fenômeno da disseminação do armamento da população no contexto da sociedade mineira colonial, ${ }^{1}$ faz-se ainda necessário refletir um pouco mais sobre a posse e uso de armas pelos escravos no cotidiano escravista evidenciando, por um lado, a ilegitimidade do fenômeno, ou seja, o cenário de crimes e violências decorrentes do armamento generalizado, e, por outro lado, sua faceta de legitimidade oriunda da dependência que a coroa portuguesa e os senhores tinham da mobilização da capacidade bélica dos escravos o que, por sua vez, revela um lado consensual da escravidão. No intuito de ponderar sobre tais questões escolhi como recorte a comarca de Vila Rica na primeira metade do século XVIII.

Carlos Lima há muito já argumentou que eram diversas as situações nas quais se esperava que escravos empunhassem armas a favor de seus senhores configurando-se mesmo um quadro de legitimidade da mobilização da violência cativa. ${ }^{2}$ No contexto inicial de organização da capitania mineira as formas de envolvimento de escravos nas diligências de seus senhores assumiam frequentemente a formação de séquitos de braços armados utilizados como recurso bélico capaz de garantir maiores sucessos nas empreitadas. Além

\footnotetext{
${ }^{1}$ Cf.: SILVA, Célia Nonata da. A teia da vida: violência interpessoal nas Minas setecentistas. Belo Horizonte: UFMG, 1998. Dissertação de Mestrado. REIS, Liana Maria. "Minas Armadas: Escravos, armas e política de desarmamento na capitania mineira setecentista". In: Varia Historia. Revista de História do Departamento da UFMG. 2004, n. ${ }^{\circ}$ 31, pp. 184-206. REIS, Liana Maria. “Criminalidade escrava nas Minas Gerais Setecentistas". In: RESENDE, Maria Efigênia Lage de \& VILLALTA, Luiz Carlos (Orgs.). História de Minas Gerais. Vol. 1. Belo Horizonte: Autêntica, 2007. PAIVA, Eduardo França. "De corpo fechado: o gênero masculino, milícias e trânsito de culturas entre a África dos mandingas e as Minas Gerais da América, no início do século XVIII". In: LIBBY, Douglas Cole \& FURTADO, Júnia F. Trabalho livre, trabalho escravo: Brasil e Europa, séculos XVIII e XIX. São Paulo: Annablume, 2006. SALES, Izabella Fátima Oliveira de. Difusão, status social e controle de armas na Mariana Setecentista (1707-1736). Juiz de Fora: UFJF, 2009. Dissertação de Mestrado.

${ }^{2}$ LIMA, Carlos A. M. “Escravos de Peleja: a instrumentalização da violência escrava na América portuguesa (1580-1850)”. In: Revista de Sociologia e Política. 2002, ํ‥ 18, pp, 131-152, passim.
} 
disso, se constituíam em sinal distintivo do poder e capacidade de mando do senhor. Importante ressaltar que Minas era nos primórdios do Setecentos um espaço de fronteira que precisava ser conquistado. Esse contexto da capitania mineira foi inundado por revoltas, motins e lutas intra-elites para definir territórios de mando em uma região nova, busca por novas áreas de mineração, pelo sertanismo, além de ser marcado pelo surgimento de quilombos e pelas preocupações em se fiscalizar e cobrar o quinto real de um produto que há tempos a coroa lusa buscava. Em todas essas situações os homens que tinham condições (materiais e imateriais) de se envolver nelas o fizeram sempre contando com o auxílio de sua força armada particular composta por cativos, pois sem isso a atuação e chances de sucesso seriam impraticáveis. Portanto, acompanhados de seus escravos armados, atuaram sistematicamente em combate a levantes e conflitos, internos e externos, na cobrança e transporte de impostos, no povoamento de novos territórios a fim de angariar mercês e reconhecimento social. São vários os relatos encontrados na documentação do Arquivo Histórico Ultramarino e no Arquivo Nacional da Torre do Tombo, concernente a pedidos e mercês régias, nos quais as situações descritas são mencionadas. Nesses pedidos de mercês os súditos buscavam demostrar sua fidelidade e zelo nos serviços prestados a sua Majestade que os habilitava ao agraciamento com patentes militares, cargos, títulos, etc., devido ao risco de suas vidas, uso de suas fazendas e emprego de seus escravos armados. A seguir alguns exemplos.

Paulo Rodrigues Durão, natural de Évora, Coutos de Alcobaça, migrou para a América Portuguesa e sertanejou nas Minas Gerais em seus primórdios sendo dos seus primeiros descobridores e povoadores. Estabeleceu-se inicialmente no Morro Vermelho do Sabará, mudando-se depois para o Inficcionado, local no qual ganhou patente de capitão de auxiliares. Tal posto exerceu entre janeiro de 1718 a dezembro de $1719 .{ }^{3}$ Em várias ocasiões atuou na conquista do território mineiro com seus cativos armados:

Como no socorro que deu com seus escravos armados ao tenente general João da Costa Fragoso para se prenderem e castigarem alguns negros revoltosos de régulos insolentes de Catas Altas em Mato Dentro que andavam armados cometendo várias desordens sem atenção aos bandos do

\footnotetext{
${ }^{3}$ FRANCO, Francisco de Assis Carvalho. Dicionário de Bandeirantes e Sertanistas do Brasil. Belo Horizonte: Itatiaia; São Paulo: Ed. USP, 1989, p. 145. Ver também: Arquivo Nacional da Torre do Tombo. Registro Geral de mercês. Paulo Rodrigues Durão. Patente. João V, livro 12, folha 302, microfilme 161.
} 
Conde de Assumar que havia proibido aos negros o uso de armas para praticar insultos que até sua chegada a estas Minas sucediam. ${ }^{4}$

Ajudou ainda o Conde de Assumar em 1720 na repressão ao levante de Vila Rica com "todos os seus escravos armados sustentando todos as suas custas no que fez com considerável despesa de sua fazenda". ${ }^{5}$ Atuou também na cobrança dos quintos do distrito do Inficcionado "com grande atividade sem queixas dos moradores sustentando soldados e escravos usados na diligência a suas custas". ${ }^{6}$

Por ter prestado tão valorosos serviços foi muito bem recompensado com várias patentes militares que atestavam seu poder e autoridade. Além da patente de capitão de auxiliares no Inficcionado, adquirida em janeiro de 1718, e da patente de capitão de ordenanças da Vila do Carmo, adquirida em janeiro de 1721, foi agraciado com a patente de sargento-mor das ordenanças do Mato Dentro em 27 de outubro de $1722 .^{7}$

Destaco também o caso de Rafael da Silva e Souza, natural do Porto, e dos primeiros povoadores das Minas. Estabeleceu-se inicialmente em Guarapiranga sendo aí nomeado capitão-mor em 1708. Nesta ocasião atuou no levante dos emboabas com 80 homens armados "gastando considerável fazenda". Tornou-se capitão dos emboabas, combatendo os paulistas "com grande zelo evitando algumas vinganças e destruição que com este levante se teve". ${ }^{9}$ Foi ainda capitão de infantaria na Vila do Carmo, sargento-mor de auxiliares na mesma localidade e coronel dos privilegiados das Minas, prestando relevantes serviços para a coroa:

Como a segurança que fez a José de Sousa Fragoso capitão de infantaria da guarnição do Rio de Janeiro que veio para as Minas para levar os quintos destas Minas para a dita cidade acompanhando com sua pessoa e negros armados para o livrar de emboscadas de seus inimigos. E sucedendo a invasão dos franceses ao Rio de Janeiro marchou para a dita cidade em socorro servindo no posto de sargento-mor de auxiliares na mesma cidade. ${ }^{10}$

Da mesma forma "atuou na sublevação passada de Vila Rica onde assistiu em defesa do Conde de Assumar com sua pessoa e escravos armados fazendo

\footnotetext{
${ }^{4}$ Arquivo Histórico Ultramarino/MG/cx.: 4; doc.: 76. Grifos meus.

${ }^{5}$ Idem, grifo meu.

${ }^{6}$ Idem, grifo meu.

${ }^{7}$ ANTT. Registro Geral de mercês. Paulo Rodrigues Durão. Patente. João V, livro 12, folha 302, microfilme 161.

${ }^{8}$ FRANCO, op. cit; p. 406-407.

${ }^{9} \mathrm{AHU} / \mathrm{MG} / \mathrm{cx} .:$ 6; doc.: 16.

${ }^{10}$ Idem, grifos meus.
} 
grande despesa a sua custa". ${ }^{11}$ Auxiliou também os governadores das Minas na delicada questão do fisco ao atuar no posto de provedor dos quintos nos distritos de Gama e Bento Rodrigues. ${ }^{12}$ Ajudou ainda na construção da casa de fundição e nas juntas para arrecadar 25 arrobas de ouro dos moradores de Vila Rica "ocasião em que era juiz ordinário e presidente da câmara da Vila do Carmo, atuando sempre com os oficiais de ordenanças e escravos nas diligências da cobrança de donativos e para conservar a paz". ${ }^{13}$

Por tantas ações valorosas ganhou várias mercês. Isso é evidenciado, por exemplo, pela sua ascendente carreira militar. Ao longo de sua vida foi adquirindo patentes de mais alto escalão passando de capitão de ordenança de pé a sargento-mor de ordenanças, em seguida a capitão-mor de ordenanças, até chegar a coronel das companhias de privilegiados e reformados e mais nobreza, sendo todos os postos exercidos na Vila do Carmo. Além disso, conseguiu também a mercê de vários cargos administrativos tais como o de provedor dos quintos, o de intendente da fazenda e o de ajudante de governo. ${ }^{14}$ Tornou-se ainda cavaleiro da Ordem de Cristo. ${ }^{15}$

Outro exemplo é o de Antônio Correia Sardinha. Natural de Évora saiu bem jovem de sua terra natal. Teve sua primeira experiência migratória ainda no reino ao sair de Évora em direção a corte "para onde foi sem consentimento de seus pais só por impulso, e por este motivo se viu obrigado a trabalhar como alfaiate". Passado um tempo na corte "sem embargo dos seus poucos anos conveniente a sua pessoa se resolveu a ir servir a Vossa Majestade. no estado do Brasil". ${ }^{16}$ Foi então para as Minas sendo também um de seus primeiros povoadores aí se tornando homem de posição social destacada. Esta era atestada pelos cargos que ocupou - foi provedor dos quintos no Inficcionado $-{ }^{17}$ e pelas patentes militares possuídas. Tornou-se "capitão de ordenanças e auxiliares donde foi promovido para o posto de sargento mor continuado desde janeiro de 1709 até outubro de 1722". 18

\footnotetext{
${ }^{11} \mathrm{AHU} / \mathrm{MG} / \mathrm{cx} .: 2$; doc.: 119. Grifo meu.

${ }^{12}$ FRANCO, op. cit; p. 406-407.

${ }^{13} \mathrm{AHU} / \mathrm{MG} / \mathrm{cx} .:$ 6; doc.: 16. Grifo meu.

${ }^{14} \mathrm{AHU} / \mathrm{MG} / \mathrm{cx} .: 11$ doc.: 15.

${ }^{15}$ ANTT. Habilitação da Ordem de Cristo de Rafael da Silva e Sousa. Letra R, maço 1, Doc. 25. Data 18 de agosto de 1745 .

${ }^{16}$ ANTT. Habilitação da Ordem de Cristo de Antônio Correa Sardinha. Letra A, maço 48, doc. 25. Data 13 de julho de 1724 .

${ }^{17}$ Idem.

${ }^{18}$ ANTT. Habilitação da Ordem de Cristo de Antônio Correa Sardinha. Letra A, maço 48, doc. 25. Data 13 de julho de 1724. Ver também: ANTT. Chancelaria Régia, João V, Antônio Correia Sardinha, patente. Livro 50, p. 254v. Data 2 de setembro de 1718.
} 
No tempo em que atuou como capitão e sargento-mor prestou vários serviços relevantes à coroa portuguesa, sempre às custas de seus cabedais, escravos armados e risco de sua vida. Tais serviços foram utilizados na petição de um hábito da Ordem de Cristo no intuito de aumentar ainda mais seu status. Neste sentido:

E sendo nomeado pelos forasteiros no posto de capitão de ordenanças da Vila do Carmo a executou e defendeu aqueles moradores das insolências que naquele tempo se costumavam fazer por causa das alterações que ali havia e falta de ministros de justiça e em 1711 reconhecendo o governador daquelas minas Antônio de Albuquerque Coelho o valor e acerto com que se tinha havido nas ocasiões que se oferecerão do sossego e conservação daqueles povos o nomear no posto de capitão de uma das companhias do terço que levantou no distrito da dita Vila lhe encarregou participasse aos povos dela o donatário que se pediu para continuação da guerra e o cobrar o que executou com grande zelo e com o mesmo acompanhou ao dito governador com a sua companhia na marcha que fez em socorro do Rio de Janeiro que se achava invadido pelos franceses executando com grande prontidão as ordens que lhe foram distribuídas e fazendo considerável despesa de sua fazenda com vinte escravos seus armados a sua custa perdendo o serviço deles em todo o tempo que durou a expedição do dito socorro em que lhe morrerão dois (...). Em 1715 fazer prisões de alguns facinorosos e negros salteadores que remeteu ao governador o que executou com perigo de sua vida, em 1718 lhe agradeceu o Conde de Assumar o cuidado e diligência com que fez varias prisões encarregando o no mesmo ano como mais benemérito do ofício de provedor do quintos reais do distrito do Inficcionado pelo conceito que se fazia de sua pessoa. Em 1719 acompanhara ao tenente general daquele governo com quarenta homens armados sendo muitos dos seus escravos, marchando a uma grande distância por caminhos ásperos e temporais rigorosos para efeito de prenderem e castigarem os pretos de um regulo que faziam insolências e hostilidades assistindo aonde foi necessário o tempo bastante para o castigar e prender os ditos negros com grande pólvora e bala a sua custa para armar a sua gente. No ano de 1720 marchar por ordem que teve para o ribeirão com o maior número de armas que podia para atalhar os mal intencionados que intentavam tumultos contra o governador procedendo com o mesmo acerto quando se viu de regente no arraial do Inficcionado executando as ordens que se lhe mandavam como foi prender a um homem revoltoso o que fez a todo custo e risco de vida. ${ }^{19}$

Por fim destaco o caso de Manuel Jorge Coelho. Natural de Évora, Coutos de Alcobaça, foi também dos primeiros descobridores e povoadores das Minas Gerais. Eleito capitão-mor de Catas Altas em $1718,{ }^{20}$ encontrei relatos de pelo

\footnotetext{
${ }^{19}$ Idem. Grifos meu.

${ }^{20}$ ANTT. Registro Geral de mercês. Manuel Jorge Coelho. Patente de capitão-mor. João V, livro 10, folha 395 v.
} 
menos duas diligências em que levou seus escravos como braço armado. No ano de 1720:

Tendo-se notícias que no mato do Caraça havia um quilombo de negros fugidos donde faziam muitos roubos e mortes aos passageiros lhe ordenou o governador Conde de Assumar que fosse com os moradores do seu distrito a castigar os ditos negros o que executou com muito acerto, sustentando a gente que levou em sua companhia e o seus escravos armados a suas custas todo o tempo que durou a dita diligência. ${ }^{21}$

Ainda em 1720 foi novamente chamado pelo Conde de Assumar a uma junta que este realizou para acabar com as desordens ocorridas naquele ano em decorrência das novas arrecadações do quinto que estavam sendo postas em prática, motim que ficou conhecido como revolta de Vila Rica. Nesta ocasião:

Foi acudir ao governador e castigar a enormidade de tão grave delito e o dito acompanhou o governador com bastante homens brancos armados e os seus escravos sustentado tudo a sua custa em todo o tempo que durou a diligência no que fez uma considerável despesa. ${ }^{22}$

Por todos esses serviços requisitou e alcançou várias mercês que lhe propiciaram ascender e tornar-se homem de prestígio social elevado com considerável poder de mando. Dentre estas mercês destacam-se a patente de capitão-mor, o cargo de provedor dos quintos reais e o hábito da Ordem de Cristo. ${ }^{23}$

A partir dos relatos mencionados fica claro que o armamento particular de escravos feito pelos senhores que necessitavam de uma guarda pessoal para atuar em situações variadas constituía-se em algo corriqueiro na primeira metade do século XVIII. Tal prática era encarada como fulcral enquanto recurso que aumentava o sucesso das diligências, além de ser vista como símbolo de poder pessoal e demonstração de prestígio para homens que se consagraram como membros da elite local. Na verdade, a prática de armar seus próprios escravos, seja para lutar em guerras, seja para entrar em confrontos diversos, era difundida em quase todas as sociedades escravistas e também o foi no Brasil. Respeitando suas especificidades regionais, a utilização por parte das autoridades e dos poderosos locais de guerreiros indígenas, escravos armados,

\footnotetext{
${ }^{21} \mathrm{AHU} / \mathrm{MG} / \mathrm{cx} .:$ 16; doc.: 3. Grifo meu.

${ }^{22}$ Idem, grifo meu.

${ }^{23}$ ANTT. Registro Geral de mercês. Manuel Jorge Coelho. Tença com habito e carta de padrão. João V, livro 21, folha 172.
} 
"desclassificados" e indivíduos livres pertencentes às camadas populares no âmbito bélico foram práticas comuns nas diversas partes da América portuguesa. ${ }^{24}$ Alguns autores ressaltam que pegar em armas para, eventualmente, lutar em diversos tipos de conflitos ao lado de seus senhores era considerada uma extensão dos serviços usualmente prestados pelos cativos..$^{25}$ Era, desse modo, crucial para as elites manter uma base local de sustentação política a partir do reforço de vínculos fortes com os escravos para com isso garantirem seu poder de mando.

Contudo, o fenômeno do armamento cativo revela também como a escravidão se sustentava a partir de um lado consensual. A interação com os escravos na formação de séquitos privados utilizados como força armada particular se realizava por meio de relações que muito provavelmente ultrapassava a simples coerção e uso da força. Nesses casos em que, em última instância, o senhor necessitava da colaboração dos escravos, de manter relações de confiança para que ao armá-los os mesmo não se rebelassem, seria muito mais lógico que ele estabelecesse relações de negociação com seu cativo nas quais cada parte interagia visando o que lhe fosse mais benéfico. ${ }^{26} \mathrm{Em}$ outros termos, não é incorreto dizer que a "subordinação" dos escravos não podia ser feita apenas via coerção, armas e castigos. Tal "subordinação" envolvia também negociações e reciprocidades, ${ }^{27}$ ou, como bem destacou Carlos Lima, do ponto de vista do escravo, deve ter envolvido algo centrado na possibilidade de barganhar as condições do cativeiro. ${ }^{28}$ Segundo esta linha de análise, considero que a rebelião e o aquilombamento não foram os únicos meios tomados pelos cativos a fim de reagirem e sobreviverem na sociedade escravista. ${ }^{29}$

\footnotetext{
${ }^{24}$ GOMES, José Eudes Arrais Barroso. As milícias D’El Rey: tropas militares e poder no Ceará setecentista. Rio de Janeiro: FGV, 2010, p. 92-93.

${ }^{25}$ Cf.: FINLEY, Moses. Escravidão antiga e ideologia moderna. Rio de Janeiro: Graal, 1991. LOVEJOY, Paul. A escravidão na África: uma história de suas transformações. Rio de Janeiro: Civilização Brasileira, 2002. BROWN, Christopher Leslie and MORGAN, Philip D. (orgs.). Arming Slaves: From Classical Times to the Modern Age. New Have \& London: Yale University Press, 2006.

${ }^{26}$ Para maiores informações sobre o tema ver: FRAGOSO, João. “Alternativas metodológicas para a história econômica e social: micro-história italiana, Fredrik Barth e a história econômica colonial”. In: ALMEIDA, Carla Maria Carvalho de e OLIVEIRA, Mônica Ribeiro de. (Orgs.). Nomes e números: alternativas metodológicas para a história econômica e social. Juiz de Fora: Ed. da UFJF, 2006. FRAGOSO, João. "A formação da economia colonial no Rio de Janeiro e de sua primeira elite senhorial (séculos XVI e XVII)". In: FRAGOSO, João; BICALHO, Maria Fernanda \& GOUVÊA, Maria de Fátima (Orgs.). O Antigo Regime nos trópicos: a dinâmica imperial portuguesa (séculos XVI - XVIII). Rio de Janeiro: Civilização Brasileira, 2001.

${ }^{27}$ FRAGOSO, “A formação da economia colonial no Rio de Janeiro", op. cit; p. 58.

${ }^{28}$ LIMA, op. cit; p. 139.

${ }^{29}$ ENGEMANN, Carlos. "Da comunidade escrava: Rio de Janeiro, séculos XVII-XIX”. In: FLORENTINO, Manolo (Org.). Tráfico, cativeiro e liberdade. Rio de Janeiro, séculos XVII-XIX. Rio de Janeiro: Civilização Brasileira, p. 173-174.
} 
No entanto, essa questão do armamento dos escravos era muito polêmica. Mesmo nos casos em que eram utilizados para a defesa pessoal num contexto de violência marcante ou em diligências em prol da coroa portuguesa, o fenômeno não deixou de fomentar dúvidas e discussões quanto à medida certa de seu emprego. Não por acaso, tentativas de regulamentação do porte de armas não foram poucas e toda uma legislação que defendia o uso moderado das armas e a proibição de armar escravos na capitania indica que, apesar de corriqueiro, isso era algo que preocupava as autoridades coloniais. Em artigo publicado em 2004, Liana Reis alertava para a necessidade de se analisar o uso de armas pelos habitantes das Minas e as tentativas metropolitanas de desarmamento como uma forma de aumentar o controle sobre a população mineira. A legislação de controle de armas, promulgada desde as primeiras décadas do Setecentos nas Minas, eram um sinal de como a população, livre e escrava, tinha acesso a armas. As proibições do uso de armas, notadamente pelos cativos, foram-se repetindo ao longo do século XVIII, o que demonstrou o seu não cumprimento e, portanto, a necessidade de reiterá-las constantemente. ${ }^{30}$ Com efeito, por todo o Setecentos vários bandos, ordens e cartas régias foram emitidas proibindo aos "cativos, negros e mulatos o uso de todo tipo de armas", particularmente as de fogo, embora sem muito sucesso. ${ }^{31}$ As autoridades e colonos temiam que, portando armas, os cativos tivessem mais força para se rebelar contra o domínio escravista. ${ }^{32}$

São vários os exemplos desta legislação que nos sugere tal fato. A ordem régia datada de 28 de março de 1714 aprovou um bando lançado pelo governador das Minas e São Paulo D. Brás Baltasar da Silveira no qual ficou estipulada a proibição do uso indiscriminado de armas de fogo. O uso destas só seria permitido aos principais quando fossem às suas fazendas ou a qualquer outra diligência, mas não aos seus escravos. Dom João justificou que a proibição era conveniente porque os cativos eram os "maiores provocadores de insultos". ${ }^{33}$ Em 29 de dezembro de 1717 o governador Conde de Assumar publicou um bando proibindo "os mineiros de juntar armas e trazê-las sem ordem sua", do contrário os infratores teriam suas fazendas sequestradas, e "que nenhum negro, mulato, carijó ou bastardo poderia portar armas nem bastões, sob pena de serem açoitados pelas vias públicas". ${ }^{34}$ Nesse mesmo ano regulamentou

\footnotetext{
${ }^{30}$ REIS, “Minas Armadas”, op. cit; p 187-189.

${ }^{31}$ REIS, "Criminalidade escrava nas Minas Gerais Setecentistas", op. cit; p. 478.

${ }^{32}$ SALES, op. cit; p. 34.

${ }^{33}$ Arquivo Público Mineiro, Livro (1), 1709 - 1721, fl. 21v. Apud: SALES, op. cit; p. 34.

${ }^{34}$ RAPOSO, Luciano \& CAMPOS, Maria Verônica. Códice Costa Matoso. Belo Horizonte: Fundação João Pinheiro,
} 
que "o uso de armas (inclusive bastões ou paus guarnecidos de castões de metal, ou paus agudos, porretes e machadinhas) por negros, mulatos, bastardos ou carijós continuava proibido" 35 , mas os escravos que estivessem acompanhados de seus senhores poderiam conduzir armas lícitas e não proibidas por lei. ${ }^{36}$ Outro exemplo se encontra em uma carta régia datada de 24 de julho de 1711 que dissertava sobre uma autorização dada pelo Rei ao governador das Minas e São Paulo Antônio de Albuquerque Coelho de Carvalho para conceder o uso de armas aos moradores da localidade. Nesta carta, os oficiais da câmara de São Paulo propuseram que fosse concedido aos escravos o porte de armas, pois na opinião deles essa era a única forma que os senhores tinham de se proteger dos perigos que surgiam nas serras e montanhas por onde andavam. ${ }^{37}$ Por fim, destaco um bando datado de 24 de março de 1719, publicado na Vila do Carmo, proibindo "o porte de armas, de qualquer espécie, aos negros, mulatos cativos ou forros". ${ }^{38}$ Tal bando negou ainda o direito dos senhores de armarem seus cativos. Também foi vetada a venda de pistolas, clavinas, espingardas, bacamartes, punhais, espadas, adagas e pólvora. Apesar de todo este aparato legal, a constante reedição dos bandos e o reforço que as autoridades aplicavam em relação a algumas leis seria um indício, como já indicado, de que as regras em relação ao porte de armas não estavam sendo cumpridas pela sociedade. ${ }^{39}$ Segundo Liana Reis, essa característica seria consequência das redes relacionais estabelecidas entre os colonos, na medida em que viabilizavam o acesso e o uso das armas. Um exemplo seria a relação estabelecida entre quilombolas e determinados grupos sociais, especialmente os donos de tabernas e vendas. Muitos comerciantes acobertavam a fuga dos cativos e forneciam a eles mercadorias, que incluíam armas e pólvora. Esse posicionamento garantia o acesso dos quilombolas aos gêneros necessários à sua sobrevivência e ao mesmo tempo se constituía em uma fonte de lucro para os homens de negócio. Além disso, segundo a autora, essa relação marcaria a opção da sociedade em estabelecer uma convivência com aqueles que fugiam do cativeiro..$^{40}$

\footnotetext{
vol. I e II, 1999, p. 336.

${ }^{35}$ Idem.

${ }^{36}$ SALES, op. cit; p. 34-35.

${ }^{37}$ Revista do Arquivo Público Mineiro, Vol. I, ano XVI, 1911. Belo Horizonte, Imprensa Oficial de Minas Gerais, título 22, p. 461.

${ }^{38}$ Idem.

${ }^{39}$ SALES, op. cit; p. 35-37.

${ }^{40}$ REIS, “Minas Armadas", op. cit; p.196.
} 
Vários eram então os perigos que podiam advir do armamento dos escravos tais como fugas, formação de quilombos, rebeliões, aquisição de experiência militar, conhecimento de armas. ${ }^{41}$ Ademais, é importante considerar também que a presença de escravos armados podia afetar as relações entre estes e senhores, possivelmente oferecendo maior poder de barganha e negociação a uma parte da população que permaneceu no cativeiro. ${ }^{42}$ Tal situação pode ser compreendida ao se levar em consideração o fato desses instrumentos, apesar de apresentarem muitos inconvenientes na sua utilização, ocuparem um lugar importante durante o desbravamento do sertão e no processo de definição das hierarquias sociais. ${ }^{43}$ Por isso, apesar dos riscos, os senhores precisavam munir seus escravos de facas, facões, paus e até mesmo armas de fogo para que esses realizassem diversos tipos de trabalhos, tais como: diligências em que prestavam serviços ao monarca, proteção ao percorrerem estradas e caminhos inóspitos em que estavam sujeitos a roubos e auxílio em contendas pessoais. Ou seja, em várias situações os senhores permitiam a seus escravos usar armas. O comentário de Donald Ramos é esclarecedor:

A dificuldade residia na falta de disposição dos senhores para dispensar a
proteção de guarda-costas escravos, daí a maioria dos editais fazerem exceção a
escravos acompanhados de seus senhores. O treinamento com armas recebido
pelos escravos sem dúvida os ajudaria caso fugissem, e é possível que os
calhambolas também se beneficiassem desse treinamento. Acrescente-se que os
diversos editais limitando a disponibilidade de armas e munição não impediram
que os escravos as obtivessem, bem como os calhambolas. ${ }^{4}$

Percebe-se assim a dificuldade de legislar sobre a posse, o porte e a utilização de armas nas Minas. Em determinados momentos o uso de armas, sobretudo por parte dos escravos, se apresentava como um grande problema na medida em que esses instrumentos se constituíam em elementos de definição da condição social, além de tornarem a rebeldia escrava contra os senhores bem mais ameaçadora. Porém, em outras ocasiões, e isso desde o

\footnotetext{
${ }^{41}$ LANDERS, Jane. "Transforming bondsmen into vassals: arming slaves in colonial Spanish America". In: BROWN, Christopher Leslie and MORGAN, Philip D. (orgs.). Arming Slaves: From Classical Times to the Modern Age. New Have \& London: Yale University Press, 2006, p. 133.

${ }^{42}$ MOREIRA, Vânia Maria Losada. "Entre índios ferozes e negros do mato: antinomias da construção da ordem nos sertões do Espírito Santo durante a primeira metade do século XIX". Anais do XXIV Simpósio Nacional de História. São Leopoldo, Rio Grande do Sul, julho de 2007, p. 15.

${ }^{43}$ SALES, op. cit; p. 31-33.

${ }^{44}$ RAMOS, Donald. "O Quilombo e o Sistema escravista em Minas Gerais no Século XVIII". In: REIS, João José e GOMES, Flávio dos Santos (Orgs.). Liberdade por um fio: história dos quilombos no Brasil. São Paulo: Cia das Letras, 1997, p.185.
} 
início da ocupação da capitania mineira, senhores necessitavam armar seus escravos para garantirem sua defesa, a de suas propriedades e para prestarem serviços ao Rei. Assim, dentro deste contexto, a posse de armas e a possibilidade de mobilizar homens para lutar eram fatores fundamentais no processo de definição do poder e conquista do território. E a coroa contava com o poderio bélico de seus vassalos para manter a ordem e defender os interesses imperiais. Não por acaso todos os segmentos sociais armavam-se independentemente dos controles governamentais.

Além dessa faceta da legitimidade do uso de armas na capitania mineira na primeira metade do século XVIII, cabe também analisar a ilegitimidade do fenômeno. Em outros termos, se era notória a utilidade que o escarvo armado possuía, não só para o exercício do poder de homens que buscavam o mando nessa região recém-conquistada, mas também para a própria coroa que deles necessitava para governar uma região tão longínqua e fulcral para o império lusitano, a disseminação de armas entre livres e, sobretudo, escravos, gerou temores e tensões devido à violência generalizada que se impunha cada vez mais no cenário mineiro do início do Setecentos.

Indícios dessa situação podem ser visualizados em processos criminais produzidos no período abordado pela pesquisa. Na Casa Setecentista de Mariana e no Arquivo da Casa do Pilar de Ouro Preto, para o período de 1710-1750, encontrei 35 processos criminais nos quais escravos são arrolados como réus e/ou vítimas de variados tipos de crime. Essa documentação capta elementos de soluções muitas vezes finais, momentos de violência que representaram o rompimento de relações possivelmente antecedidas por acertos - convencionados de maneira verbal ou não - entre livres e cativos cotidianamente. ${ }^{45}$ Os processos criminais revelam o dia-a-dia das relações pessoais de dominação e exploração no universo escravista ${ }^{46}$ as situações em que o armamento levava a conflitos e violências e, por outro lado, como a negociação se constituía em elemento crucial da relação senhor-escravo.

A título de exemplo assinalo o processo crime de Manoel da Costa Monis, morador no Gualacho do Sul, termo da Vila de Nossa Senhora do Carmo, que denunciou ao juiz de fora o seu sócio Guilherme Fixer. Ambos tinham sociedade em um sítio no qual existiam várias lavras. Nestas, Manoel da Costa Monis empregava alguns escravos que possuía fora da sociedade com Guilherme

\footnotetext{
${ }^{45}$ FERREIRA, Ricardo Alexandre. Escravidão, criminalidade e cotidiano. Franca, 1830-1888. Franca: UNESP, 2003. Dissertação de Mestrado, p. 16 e 40.

${ }^{46}$ LARA, Sílvia H. Campos da violência: escravos e senhores na capitania do Rio de Janeiro - 1750-1808. Rio de Janeiro: Paz e Terra, 1988, p. 24.
} 
Fixer no serviço de minerar e cultivar roça. Segundo o querelante, no dia 19 de maio de 1735, ao se ausentar para fora da freguesia, um de seus escravos chamado Alexandre de nação Mina foi faiscar "em um córrego da mesma fazenda lugar que já se havia lavrado e vendo o querelado que aborrecia com grande ódio a ele querelante e as suas coisas sem motivo algum fora ao dito negro e lhe dera várias pancadas com um bordão com os quais lhe fizera ferida". ${ }^{47}$ Segundo Alexandre, 0 réu o mataria se ele não fugisse. Com o depoimento de João Lopes Vitória, testemunha do crime, tem-se a dimensão da agressão feita contra Alexandre Mina. Esta provocou três feridas na vítima:

Uma por cima da sobrancelha do olho esquerdo do comprimento de uma polegada e assim mais lhe vi duas juntas no alto da cabeça, e uma delas pendente para a parte esquerda ambas de comprimento de meia polegada todas três de couro e carne e uma delas sanguenta. ${ }^{48}$

As pancadas foram tão violentas que o referido escravo permaneceu 20 dias sem trabalhar. Dessa forma, Manoel da Costa Monis exigia que o querelado fosse castigado conforme merecia, pois o número de dias que seu escravo deixou de trabalhar constituía-se em grande prejuízo para ele. Ademais, na visão do querelante, o réu não poderia ter aplicado um castigo em seu escravo que colocasse em risco a vida do cativo ou que impedisse a execução das tarefas diárias, visto que ele era um bem material, usado como força de trabalho.

Na pronúncia o juiz de fora ordenou que Guilherme Fixer fosse preso e o declarou culpado. Mas, na sentença do ouvidor geral, o réu foi considerado inocente por agir em legítima defesa. Durante sua defesa o réu Guilherme Fixer alegou o seguinte:

Vindo ele da missa e um seu feitor achou seu moinho parado e foi a tapar umas sobras de água de Francisco Lobo da Gama que ajuntava com a sua para o dito moinho e achou o dito negro Alexandre faiscando e lhe perguntou para que abria a dita água lhe respondeu que estava trabalhando com água de seu senhor. ${ }^{49}$

O réu não acreditou na palavra do escravo, visto que essas águas eram as sobras de Francisco Lobo da Gama e, pelo fato de ser dia santo em que não se deveria trabalhar, afirmou que "tinha a obrigação de sustentar 27 pessoas e que essa tarefa era mais importante do que a faisqueira dos negros”. Disse ainda:

\footnotetext{
${ }^{47}$ Arquivo da Casa Setecentista de Mariana. Processo crime. Códice 205, auto 5134, 2º ofício (1735).

${ }^{48}$ Idem.

${ }^{49}$ Idem.
} 
Que pela aspereza com que o negro lhe respondeu deu com um bordãozinho que levava na mão e logo puxou o dito negro por uma faca ao réu com ânimo deliberado a matá-lo e com efeito o feriu em três partes em uma mão o que não conseguiu o dito negro por ir um seu feitor e em alguma forma desviou o dito negro a que o não ferisse mais. ${ }^{50}$

Pelos relatos acima é possível resgatar várias informações valiosas acerca do convívio, formas de agir e pensar dos envolvidos que podem também, em certa medida, auxiliar na compreensão de algumas questões propostas, tais como: o armamento dos escravos, os riscos daí resultantes, a existência de concessões e negociações entre eles. De fato, constatei que o escravo em questão andava armado, no caso portava uma faca, uma arma proibida por lei aos cativos e com o consentimento de seu senhor. Levando em consideração que o dito escravo tinha fama de ser mal doutrinado e de já ter um histórico de crimes, ${ }^{51}$ seu senhor sabia que o risco desse escravo andar armado e de abusar dessa prerrogativa agindo com violência era grande. Mesmo assim não deixou de por arma nas mãos de seu cativo indicando que, apesar do perigo, havia nesta relação algo que o levava a tomar esta atitude. Muito provavelmente esse senhor concedeu, barganhou e negociou com seu cativo para que os riscos fossem menores que as vantagens advindas.

Além disso, como é referendado pelos autos do processo, Manoel Monis tinha fama de ser "um homem violento que ameaça com facadas e pancadas pessoas com quem tem tido rincões e dá armas aos seus negros e consentem a terem facas, pois outros mais deles também as trazem". ${ }^{52}$ Ou seja, para este senhor, não era nada incomum armar alguns de seus escravos e deixar que eles circulassem pelas redondezas. Nesta sociedade onde a violência era algo corriqueiro os escravos constituíam-se no elemento de manutenção e defesa de seus proprietários. Por isso armá-los - mesmo sabendo que havia riscos deles agirem com desmandos e praticarem crimes, e mesmo com a existência de uma legislação proibitiva - era muitas vezes bem mais conveniente e proveitoso.

Examinando os demais processos constatei que a maioria dos crimes se relacionava a eventos ocorridos fora da presença dos senhores graças a furtivas ou consentidas andanças dos cativos pelos mais diversos locais, culminando

\footnotetext{
${ }^{50}$ Idem.

${ }^{51}$ Consta nos autos do processo que dois anos antes da data do crime ora analisado, Alexandre foi acusado de ter dado várias pancadas em seu feitor, roubando o ouro que este trazia consigo, durante uma noite em que trabalhava nas lavras de Thomas Pereira. ACSM. Processo crime. Códice 205, auto 5134, 2ºfício (1735).

${ }^{52}$ ACSM. Processo crime. Códice 205, auto 5134, 2º ofício (1735). Grifo meu.
} 
em ações tidas como delituosas..$^{53}$ Além disso, nos casos analisados observei que o porte de armas, o ajuntamento de escravos, a mobilidade espacial que tinham, a presença dos cativos em tabernas e vendas eram elementos quase sempre presentes e facilitavam bastante a ocorrência dos crimes como lesões corporais, homicídios, furtos e roubos. A seguir alguns exemplos.

No dia 10 de julho de 1747 na cidade de Mariana, pelas 20 horas, estava Narcizo Freire Branco na venda de Manoel Pereira quando chegou na mesma Simão Courano, escravo do Reverendo Cônego Antônio Pereira da Cunha, dizendo desaforos aos presentes e ameaçando "dar uma facada em um branco". Narcizo Freire não aceitando tal afronta começou uma discussão e "declarou ao dito negro o atrevimento $e$ lhe dera um bofetão e em desagravo o dito negro se lançou a ele". Para se defender, segundo alegava o réu nos autos, "pegou uma foice de limpar e com ela fez uma ferida em um dos braços do negro (...) e porque tem notícia que se acha pronunciado nos ditos autos e teme ser preso e por isso se quer se mostrar inocente". ${ }^{54}$

Outro caso encontra-se na devassa que o juiz ordinário e sargento-mor Manoel de Freitas Ferreira mandou fazer para averiguar um furto feito em uma venda localizada no distrito de Bassão em Ouro Preto. De tal crime eram acusados Manoel de Oliveira, Mathias Thomé e João Cobu, escravos de Manoel de Meireles, homem pardo. Os acusados, em uma noite do mês de julho de 1732, arrombaram a dita venda armados com faca e assaltaram o local levando: "42 oitavas de ouro, três saias, uma de cara fina e duas de drogete, três camisas de mulher de Bretanha, duas de homem, uma rede, uma besta de camelão, um chapéu, um tacho, e dois lenços de mulher". ${ }^{5}$ Segundo a testemunha Manoel Pereira, 40 anos, também proprietário de uma venda:

Na noite e hora declaradas estando a negra de Manoel de Oliveira na sua venda sem que naquela ocasião estivesse branco algum bateu na porta desta venda um negro escravo de Manoel de Meirelles para comprar aguardente e a dita negra não lhe quis abrir a porta motivo que levou o dito negro a fazer um buraco na parede pelo qual abriu a janela e entrou pra dentro e estando sozinha começou a dita negra a gritar de sorte que o tal negro disse que não gritasse que haveria de pegar as coisas que estavam no rol do furto e sair pela janela e lá fora esperava dois companheiros seus que abriram parte da dita casa. ${ }^{56}$

\footnotetext{
${ }^{53}$ FERREIRA, op. cit; p. 96-97.

${ }^{54}$ ACSM. Processo crime. Códice 215, auto 5359, 2º ofício (1747).

${ }^{55}$ Arquivo da Casa do Pilar de Ouro Preto. Processo crime. Códice 460, auto 9781, 1o oficio (1732).

${ }^{56}$ Idem.
} 
Por fim destaco a devassa que tirou o juiz ordinário Manoel de Freitas Ferreira pela morte de Maria de nação angola escrava de André de Barros. De acordo com as testemunhas, sua morte, ocorrida aos 04 dias do mês de abril de 1732, em Vila Rica, foi acidental, pois:

Um moleque escravo de Plácido Pinto estava brincando com umas pistolas quando a negra defunta escrava de André de Barros ia descendo pelas escadas do Santíssimo e subindo pelas mesmas escadas o dito moleque sucedeu que esbarrou com a mesma negra de sorte que disparou uma das pistolas e carregar a munição na dita negra de que resultou falecer do que depois saiu fugindo. ${ }^{57}$

Nos processos nota-se que os cativos tinham uma considerável autonomia, circulando não só de dia, mas também à noite, pela redondeza, por tabernas e vendas denotando assim que tinham também espaço para sociabilidades. Constata-se ainda que andavam armados, haja vista que os crimes descritos foram cometidos com armas branca e de fogo. Estes são dados muito sugestivos que ajudam a reformular argumentos sobre o funcionamento da escravidão no contexto mineiro colonial. Estudos já apontaram que tentativas de frear os comportamentos rebeldes dos cativos não se mostraram tímidas durante a primeira metade do século XVIII na capitania mineira. Proibiamse batuques, as vendas administradas por escravos ou forros nas áreas de mineração, o comércio ambulante perpetrado pelas quitandeiras, o porte de armas pelos cativos, o trânsito descontrolado pelos caminhos..$^{58}$ Entretanto, como sugerem os dados acima, tais assertivas têm de ser relativizadas conforme a situação, necessidade e contexto. Desta forma, se a escravidão foi reinterpretada como um sistema socialmente coercitivo, foi também passível de adequações, resistências, acomodações, negociações e pactos sociais. ${ }^{59}$

Os casos acima indicam que apesar dos riscos, temores e conflitos surgidos, senhores interagiam não só de forma coercitiva, punitiva e violenta com os escravos, pois lhes davam a possibilidade de ampliar a margem de manobra para ter espaços autônomos e possibilidades de negociação. Para alguns autores isso é mesmo apontado como fulcral para explicar a estabilidade do próprio sistema escravista. Afinal, se os escravos podem ser vistos como agentes históricos que possuíam família, vida cultural e comunitária,

\footnotetext{
${ }^{57}$ ACPOP. Processo crime. Volume 1409, rolo 5124, 1ํo ofício (1732).

${ }^{58}$ Cf.: ANASTASIA, Carla M. Junho. Vassalos e rebeldes: violência coletiva nas Minas na primeira metade do século XVIII. Belo Horizonte: C/ Arte, 1998, p. 127.

${ }^{59}$ OLIVEIRA, Patrícia Porto de. "Desfazendo a maldição de Cam por meio dos assentos de batismo de escravos adultos da Matriz do Pilar de Ouro Preto (1712-1750)". In: Anais do X Seminário sobre Economia Mineira. Diamantina, Cedeplar - UFMG, 2004, p. 5.
} 
que negociavam e atuavam no mercado produzindo e vendendo bens próprios, suas atitudes também devem ser analisadas como iniciativas que respondiam a projetos próprios, que interferiam no processo de reconfiguração de relações sociais e de poder na sociedade em que se inseriam. ${ }^{60}$

Neste sentido, podemos argumentar, conforme nos indica Ira Berlin, que os escravos conseguiam ter uma compreensão da hierarquia local e da complexa dinâmica das relações de poder. Apesar da condição de escravos, conseguiam ter habilidades, conexões pessoais e famílias. Mais ainda, encontravam protetores entre os abastados e a elite, se identificavam com as mais importante instituições da colônia, registrando seus casamentos, batismos e apadrinhamento de filhos na igreja. Entravam com processos e eram processados nos tribunais locais. Desta forma, conseguiam burlar ou reformular a ideia que se tinha da servidão, pois conseguiam trabalhar por conta própria, viver a parte de seus proprietários, controlar sua vida familiar e usar armas. ${ }^{61}$ Este último aspecto, que nos interessa mais de perto, pode ser também ratificado pelo próprio fato de ser comum os escravos usarem facas, foices, machados e porretes em seu trabalho diário, apetrechos que facilmente podiam ser utilizados como armas tanto em roubos, assassinatos e desavenças entre os habitantes de inúmeros arraiais e vilas das Minas, quanto em conflitos armados que poderiam se envolver com seus senhores, como anteriormente mencionado.

De qualquer forma, não há como negar que as armas faziam parte do cotidiano cativo e senhorial, servindo tanto para fins "legais" de proteção e prestação de serviços ao Rei, quanto para fins criminosos. Neste último caso, a tabela abaixo nos mostra quais os tipos de instrumentos de agressão mais recorrentes nos autos dos processos trabalhados:

\footnotetext{
${ }^{60}$ Neste sentido ver: GENOVESE, Eugene. A terra prometida: o mundo que os escravos criaram. Rio de Janeiro: Paz e Terra, 1988. RUSSELL-WOOD, A.J.R. Escravos e libertos no Brasil colonial. Rio de Janeiro: Civilização Brasileira, 2005. REIS, João José \& SILVA, Eduardo. Negociação e conflito: a resistência negra no Brasil escravista. São Paulo: Cia. das Letras, 1989. FARIA, Sheila de Castro. A colônia em movimento: fortuna e família no cotidiano colonial. Rio de Janeiro: Nova Fronteira, 1998. PAIVA, Eduardo França. Escravos e libertos nas Minas Gerais do século XVIII: estratégias de resistência através dos testamentos. São Paulo: Annablume, 1995. GÓES, José Roberto \& FLORENTINO, Manolo. A paz das senzalas: famílias escravas e tráfico atlântico, Rio de Janeiro c.1790 - c.1850. Rio de Janeiro: Civilização Brasileira, 1997. SLENES, Robert. Na senzala uma flor. Rio de Janeiro: Nova Fronteira, 1999. SOARES, Mariza de Carvalho. Devotos da cor: identidade étnica, religiosidade e escravidão no Rio de Janeiro, século XVIII. Rio de Janeiro: Civilização Brasileira, 2000.

${ }^{61}$ BERLIN, Ira. Gerações de Cativeiro. Uma história da escravidão nos Estados Unidos. Rio de Janeiro: Record, 2006, p. 53 e 99.
} 
A tabela 1 sugere que o conceito de arma tem de ser entendido amplamente, pois qualquer coisa poderia servir como armamento. Paus, pedras, instrumentos de trabalhos (tais como machados, facões, foices, etc.) eram utensílios de fácil acesso e presença constante no dia a dia dos habitantes da região. Daí ser ainda mais difícil para a coroa e para as autoridades conseguirem ter um controle eficiente sobre o armamento dos colonos. As armas mais "sofisticadas" tais como espadas, espadins, espingardas e pistolas eram

Tabela 1: Instrumentos de agressão mencionados nos processos criminais coletados, décadas de 1710- 1750 (para os quais se tem informações)

\begin{tabular}{c|c}
\hline Armas e Instrumentos & Frequência \\
\hline Porrete & 3 \\
\hline Bordão & 1 \\
\hline Navalha & 1 \\
\hline Faca & 3 \\
\hline Espada & 2 \\
\hline Arma de fogo & 2 \\
\hline Foice & 1 \\
\hline Pedra & 1 \\
\hline Sem informação & 21 \\
\hline Total & 35 \\
\hline
\end{tabular}

Fonte: Processos crime do ACSM e do ACPOP, $1^{\circ}$ e $2^{2}$ ofícios, décadas de 1710 1750.

menos usadas pelos estratos mais empobrecidos da população, estando mais presentes entre a elite, não só por causa da legislação que proibia sua livre circulação, por serem mais difíceis de conseguir, mas por serem também usadas como signos de poder, como é o caso das espadas e espadins. Segundo António Manuel Hespanha, no contexto português diante do processo da Revolução Militar, a espada foi perdendo cada vez mais espaço nos exércitos europeus como arma de combate da infantaria. Entretanto, sua utilização nos territórios ultramarinos ainda continuava presente de maneira significativa. ${ }^{62}$ Sílvia Lara também destaca que o uso de espadas permaneceu frequente nas conquistas

${ }^{62}$ HESPANHA, António Manuel (Org.). Nova História Militar de Portugal. Vol. II - séculos XVI-XVII. Lisboa: Círculo de Leitores: 2003, p.10. 
lusitanas, a ponto de alguns segmentos da sociedade pedir permissão para utilizá-las, assim como os espadins. ${ }^{63}$

As armas assumiam assim importância fulcral na vida cotidiana das Minas. Pelo seu número media-se o poder de um homem, tendo também um valor simbólico excepcional. Generalizado em praticamente todos os estratos sociais, o porte de armas expunha o forte sentimento de insegurança desses primeiros tempos. ${ }^{64}$

\section{Considerações finais}

$O$ artigo buscou ressaltar a faceta da legitimidade e da ilegitimidade do armamento de cativos na comarca de Vila Rica na primeira metade do século XVIII. Por um lado, observou-se que os escravos ocuparam um lugar central na composição das forças utilizadas por alguns senhores para a prestação de serviços à coroa portuguesa visando mercês. Para tanto, era necessário que os senhores colocassem armas nas mãos dos escravos, o que era motivo de controvérsias e discussões. A legislação proibitiva do porte de armas e as exigências para que os proprietários desarmassem seus escravos indicam que muitos acreditavam que estas fossem práticas perigosas, mas pouco se fazia para interrompê-las. Ira Berlim nos sugere que talvez o uso das armas pelos cativos incentivasse, assim como os benefícios que podiam ganhar sendo usados como braço armado, certa noção de independência, algo que os proprietários temiam em incentivar. Já os escravos podiam considerar isso um alívio em relação à velha degradação advinda da servidão em trabalhos no eito. ${ }^{65}$

Por ouro lado, a disseminação de armas, essas compreendidas em sentido amplo, propiciava um cenário de tensão e conflitos no qual a violência se tornou algo corriqueiro, conforme apontado pelos processos criminais analisados. No que tange aos escravos, os crimes citados nos processos mostraram que eles andavam armados em seu dia a dia, que podiam circular e ter certa autonomia mesmo com os temores e riscos que advinham desta situação. Observou-se também que a arma era algo comum para os colonos de todos os estratos sociais. Devido a seu fácil acesso, sobretudo no que se refere aquelas com características mais rudimentares, tais como, os instrumentos utilizados para o trabalho nas minas e roças, era difícil para as autoridades controlar

\footnotetext{
${ }^{63}$ LARA, Sílvia. Fragmentos setecentistas - escravidão, cultura e poder na América portuguesa. Campinas: Unicamp, 2004. Tese de Livre-Docência. Ver também: SALES, op. cit; p. 65-66.

${ }^{64}$ ROMEIRO, Adriana. Paulistas e Emboabas no coração das Minas. Ideias, práticas e imaginário político no século XVIII. Belo Horizonte: Ed UFMG, 2008, p. 89 e 124.

${ }^{65}$ Ibidem, p. 113.
} 
sua posse, contribuindo ainda mais para o clima de instabilidade que podia surgir nas relações sociais estabelecidas neste contexto.

No entanto, estes mesmos elementos (a violência latente, a facilidade de conseguir armas, a ineficiência da fiscalização do uso destas) acabavam também por dar à escravidão um lado consensual, pois, do contrário, seria muito difícil sua manutenção sem eclosões de fugas, revoltas e motins a todo o momento. Toda uma historiografia clássica já destacou que o sistema escravista tinha a violência como elemento constitutivo e institucionalizado e que, desta forma, não é possível pensar a escravidão sem a violência. ${ }^{66}$ Porém, há muito também já se sabe que não é suficiente pensar a escravidão apenas por ela. ${ }^{67}$ Conforme ressaltam João José Reis e Eduardo Silva "os senhores não exerciam seu poder apenas na ponta do chicote, mas também através do convencimento de que o mundo da escravidão oferecia ao escravo - e a uns mais que a outros - segurança e mesmo um certo espaço de barganha". Por sua vez, o cativo que aparentava comportamentos acomodados e até submissos em um dia podia tornar-se o rebelde do momento seguinte, permanecendo numa zona de indefinição de acordo com as circunstâncias de suas vivências cotidianas. Em meio à tensão da sociedade escravista, negociação e conflito configurar-se-iam como os limites entre os quais senhores e escravos se relacionavam. ${ }^{68}$

Vale lembrar que esta era uma sociedade em que o tráfico africano de escravos se fez muito marcante e, neste sentido, despejava constantemente levas e levas de estrangeiros (outsiders) sociais que, na América portuguesa, se transformavam em indivíduos despidos de sua identidade social prévia, colocados à margem de um novo grupo social que lhe deveria dar uma nova identidade. Assim, para que o escravo se tornasse um membro (insider) da localidade tinha de passar por todo um processo de inserção no qual, sem dúvida, este lado consensual de negociação teve papel fulcral.

Artigo recebido para publicação em 29/12/2017

Artigo aprovado para publicação em 27/04/2018

\footnotetext{
${ }^{66}$ Cf., por exemplo: GORENDER, Jacob. O escravismo colonial. São Paulo: Ática, 1978. CARDOSO, Fernando Henrique. Capitalismo e escravidão no Brasil meridional: o negro na sociedade escravocrata do Rio Grande do Sul. Rio de Janeiro: Paz e Terra, 1977.

${ }^{67}$ ENGEMANN, Carlos. De laços e de nós: constituição e dinâmica de comunidades escravas em grandes plantéis no Sudeste brasileiro dos Oitocentos. Rio de Janeiro: UFRJ, 2006. Tese de Doutorado, p. 35.

${ }^{68}$ REIS, João José \& SILVA, Eduardo. Negociação e conflito: a resistência negra no Brasil escravista. São Paulo: Cia. das Letras, 1989, p. 9. Apud: FERREIRA, op. cit; p. 8.
} 